\title{
INTERNATIONAL TOURISM SPATIAL DISTRIBUTION: AN ALTERNATIVE CARTOGRAPHY OF WORLD TOURISM ORGANIZATION (UNWTO) DATA
}

\author{
Carolyne de Castro Carvalho Silvaa; \\ Maurício Ragagnin Pimentelb; \\ João Vitor Cepinho dos Santos ${ }^{c}$
}

\begin{abstract}
The UNWTO is responsible for collecting and disseminating International Tourism data about 200 states among its associate members and affiliates. Traditionally this information is disclosed in the Compendium of Tourism Statistics, whose access is restricted or paid. The WTO reports also present the data aggregated in accord to the regional division of the world established by the UNWTO itself. This work aims to present an alternative cartography and to discuss the spatial distribution of international tourism. This was done from the UNWTO database, available by the World Bank. The interval between 2006 and 2016 was chosen for analysis. The indicators presented are: the average of international arrivals from 2006 to 2016 ; the variation in the number of international arrivals between 2006 and 2016; the ratio between international arrivals and each country's population in 2016; the ratio between international tourism revenue and international arrivals between over 2006 and 2016; the variation in international tourism revenues between 2006 and 2016; the variation in international tourism spending between 2006 and 2016. The discussion of these indicators is important for a deeper understanding of the dynamics of international tourism, which goes far beyond the traditional debate around the often-released top ten rankings.
\end{abstract}

\section{PALAVRAS-CHAVE}

Spatial distribution of tourism

International tourism

UNWTO 


\section{INTRODUCTION}

The World Tourism Organization (UNWTO) is a United Nations agency, with the purpose to promote tourism as an instrument for peace and mutual understanding among people and as a tool for economic development. Among UNWTO's tasks is the work of coordinating and systematizing the process of collecting statistical data related to tourism in its associated states. An important work in this regard is the International Recommendations for Tourism Statistics (UNWTO, 2008). These data are traditionally released in a compiled manner in highlights annual reports (UNWTO, 2019) and a restricted access publication: the Compendium of Tourism Statistics.

Despite its importance to the public and scientific debate about tourism and its use in studies and official publications, it is rare to find academic literature discussions on these results. In this project, we found a scarce return in the search for the keywords: International Tourism, OMT, UNWTO at the following databases Spell.org, Scielo.org.br, Redalyc.org and CAPES journals portal. One exception is the work of Pieri (2014). The limitations and political implications of the concepts adopted by the organization are objects of reflection by Pimentel (2017). Tourism Geography books, such as Silveira (2015), Mesplier \& Bloc-Duraffour (2000) raise this debate, although not always updated and again presenting results based on macroregional aggregates.

However, as pointed out by Silveira (2015), the theme is important. International tourism is an agent of globalization, connecting a worldwide tourism system. "Countries that were inaccessible or poorly visited, because they are too expensive or geopolitically closed, are now being integrated into world tourism" (SILVEIRA, 2015, p. 216). Nevertheless, the author reports the levels of inequality between world tourism flows, pointing to the development of the Northern Hemisphere and the relation to tourism spaces that are considered as "support bases", noteworthily tropical resorts. The countries of the Northern Hemisphere, therefore, are the largest outbound and inbound markets on world tourism. They are also characterized by their consolidated regional tourism flows.

In Latin America, focusing on South America, tourism is unevenly spread. One factor that influences is the distance of these countries to the main tourists' origin places. There is also a lower regional GDP per capita, which directly contributes to the available income for tourism spending. In that sense, South America is a relatively less efficient area in the use of its tourism resources. Tourism investments tend to be left behind due to the region's economic and financial instability, structural unemployment, inflationary pressures and insecurity (NETTO \& TRIGO, 2016).

These authors also point that large infrastructure, as well as big hotel and resort companies, are generally established by foreign capital, resulting in revenues for the investing countries, therefore not necessarily contributing much to the local territory. The issue of cruise ships, which are routine in the region, stands out. These promote a tourism development model where tourists end up having little contact with the places they visited, not spreading their expenditures throughout the country, and frequently shipping overseas the investors' profits (NETTO \& TRIGO, 2016).

Given that context, this paper seeks to understand the recent dynamics of international tourism using UNWTO data made available through the World Bank open access indicators catalog. It aims to point out the complexity of relations between states and tourism, showing the relationship between economic, cultural, social, geographical and historical aspects. This is done by discussing three indicators and some of their variations. The indicators are: the number of international arrivals; the international tourist expenditures; and the revenues from international tourism. According to the UNWTO, the definition of these indicators is as follows. International arrivals are defined as:

The number of tourists traveling to a country other than that in which they normally reside, but outside their usual environment, for a period of fewer than 12 months and whose primary purpose of visitation is not a paid activity within the visited country (UNWTO, 2019b, Metadata).

International tourism expenditures are: "the expenditures made in other countries by international visitors that leave and payments to foreign carriers for international transport. [...] Data in US \$ at current pri- 
ces."(UNWTO, 2019c, Metadata).

On the other hand, tourist revenues are:

Expenditures incurred by visitors coming from abroad, including payments to national carriers for international transport service. This revenue includes advance payments of any class that are made for goods or services received in the destination country. It also includes revenue from visitors for a day. (UNWTO, 2019a, Metadata).

These definitions, therefore, exclude from mobilities categories as transportation crew, diplomatic members, permanent migrants, and refugees. It also covers a longer period than the traditional ninety days granted by tourist visas. International spending refers to what a country's residents spend on international travel, including transportation tickets issued by foreign companies. Revenues from international arrivals are the sum of what visitors spend in a country, including those who are citizens but live abroad and come to visit family and friends. If the expenditures are made out of the country in payment to a tour operator or carrier from the destination country, they already enter the sum of tourist revenues.

\section{METHODOLOGY}

This is an exploratory research that uses thematic cartography, descriptive statistics, and cluster analysis. Three indicators and their variations are presented: international arrivals, international tourism revenues in US \$ and international tourism expenditures in US \$. The analysis timeframe is between the years 2006 and 2016. As a result, we made thematic maps from the following indexes: 1 ) average of international tourist arrivals; 2) number of international tourist arrivals per country's population in 2016; 3) variation in the number of international arrivals between 2006 and 2016; 4) international tourism revenues in US \$; 5) variation in international tourism revenues between 2006 and 2016 ; 6) average of international tourist spending; 7) variation in international travel spending between 2006 and 2016; 8) revenues from international tourism; 9) variation in international tourism revenues between
2006 and 2016. The WTO dataset available on the World Bank's catalog covers the years 1995 to 2017. However, we chose to analyze the decade from 2006 to 2016 because it was the period with more complete and uniform data between the different states. The software GeoDa was used to categorized into seven groups utilizing the Natural Breaks method. The maps were then made using QGis software, version 2.14 .

\section{RESULTS}

\section{Average of international arrivals (2006-2016)}

From the map in Figure 1 (attachment) it is evident that the largest arrival flows are in the Northern hemisphere countries, while those in South have the lowest rates. The countries hosting the largest flows have a tradition as a destination, as well as a better infrastructure to receive tourists and being near to nations with higher disposable income for travel. With significant advantage, France is the country with the largest number of international arrivals, exceeding eighty million a year. The United States, Spain, China, and Italy come next in the ranking of international tourists' main hosts.

Figure 01 - Average of International tourist arrivals between 2006 and 2016

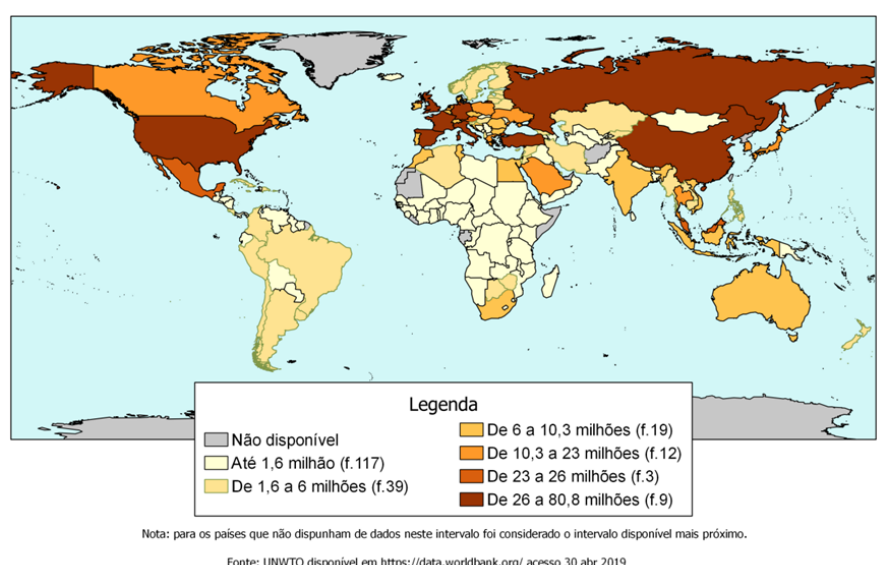

Foret

Source: elaborated by the authors.

The countries' different geographical situation makes problematic their simple comparison, as often made 
from rankings. That is due to the regional tourism system peculiarities, such as income concentration, tourism infrastructure, and air routes greater offer in the Northern Hemisphere (MESPLIER; BLOC-DURAFFOUR, 2000). For example, one of the reasons France is the world's main recipient is that it borders seven nations, being in northern and southern Europe crossroads. A situation which is different from that of Spain.

\section{Number of international arrivals per population (2016)}

By analyzing the product between the number of international arrivals (Figure 2) and each country's population in 2016 (UNITED NATIONS, 2019) it is clear that some countries are more specialized in tourism than others, even though they might receive fewer visitors in absolute terms. This is evident in the nations depicted with darker tones on the map. The darker tone of the analysis fills countries exclusively in the Northern Hemisphere. The highest indexes refer to small states, such as Andorra, which has the largest index on the map. This European country has 77,281 inhabitants and received 2,831,000 international arrivals in 2016. The most populous country that fits this category is also European: Austria. Nonetheless, Asia also stands out, with places like Macao Chinese territory which hosted 15,706,600 international arrivals in 2016 having

Figure 02 - 2016 International tourist arrivals and countries population ratio

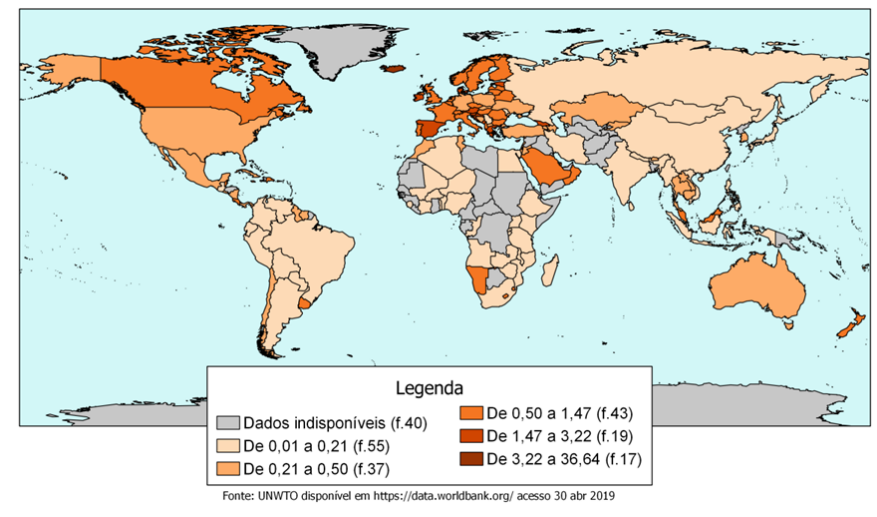

Source: elaborated by the authors.

a 612,167 people population (UNWTO, 2019). Other highlights are the Caribbean countries, which are highly tourism-dependent.

Regarding the Southern Hemisphere, one highlight Uruguay in South America, with statistics that would make it comparable to established destinations like France and Italy. In Africa, Lesotho, Swaziland, and Namibia stand out with the indexes: $0.54 ; 0.71$; and 0.59 . In Oceania, something similar to the Caribbean happens, but to a lesser extent, like New Zealand, Samoa, Tonga, French Polynesia constitute a set of islands that fit the same index, especially Fiji, which has 0.88 in scale. In this continent, the highlight is New Zealand. It is important to note that for many countries on the map, especially in Africa, data for 2016 is unavailable.

\section{Variation in the number of international tourist ar- rivals (2006-2016)}

In the map of international tourist arrivals variation between 2006 and 2016 (Figure 3), it is possible to assess the global tourism growth dynamics. The image shows that the biggest variations in international arrivals are in the Republic of Congo, Central African Republic, and Burma. Countries with little tourists' flow in which a new political stability situation had a positive effect on the welcoming of visitors. Besides, the map also displays an evident increase in tourism in Southeast Asia.

Figure 03 - Variation of international tourist arrivals between 2006 and 2016

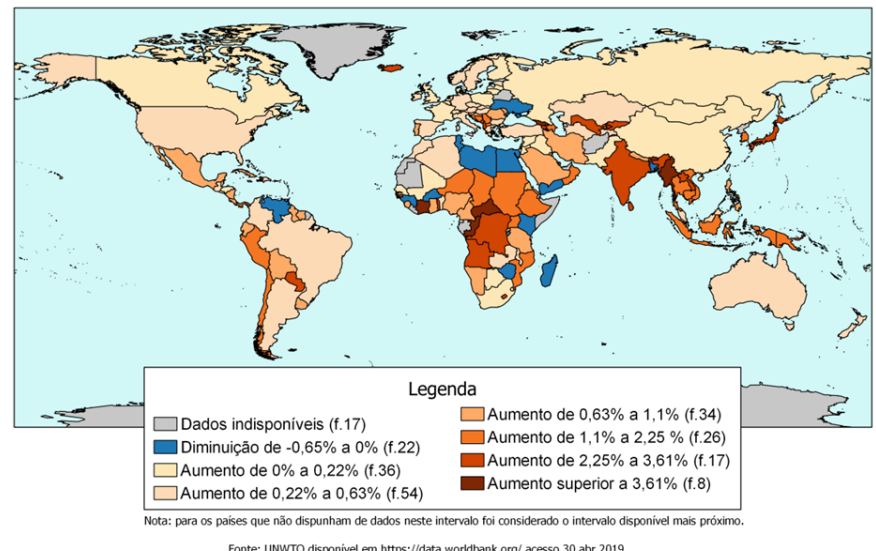

Source: elaborated by the authors. 
In opposition to this situation, are the countries with a negative variation in this period, such as Venezuela, Madagascar, Philippines, Bangladesh, Egypt, Libya, Ukraine, Tunisia, Zimbabwe, Tanzania, Guinea, Burkina Faso, and Yemen. In these states, the decrease was generally due to political and ethnic conflicts, dictatorial regimes closed to international trade, or natural disasters and terrorist attacks. Overall, the countries that had the largest variations, both positive or negative, are in areas peripheral to North America and Europe, except for Ukraine. In the case of Northern African, the political instability or safety concerns due to movements such as the Arab Spring had a direct impact on these countries' tourist flows. On the other hand, in Southeast Asia, a new air traffic agreement between China and the ASEAN members resulted in a greater tourist flow between the region's countries (LENOIR \& LAPLACE, 2016).

\section{Revenues (US \$) for international arrivals}

The map of the quotient between the average of international tourism revenue in US dollars and the number of international arrivals between 2006 and 2016 (Figure 4 ) indicates the value that tourism has to each nation's economy. There are few countries at the highest values category, represent by the map's darkest color. They are specifically: Luxembourg, Australia, Lebanon, Libya, Qatar, and Switzerland. These countries got a \$3,271 to $\$ 5,234$ revenue average for each international arrival. Australia is the only country in the Southern Hemisphere. Two reasons may characterize such a situation: tourists have a longer stay in these countries, or they have more expensive tourism services. It is also worth pointing out that nations that stand out in other indicators, such as France, China, and Mexico, are in the lower positions in this index.

When comparing South American and European tourism through this variable it is possible to argue that Brazil, Argentina, and Peru fit the same class as countries such as Spain or Italy, and are even superior to traditional destinations like Mexico, France, and China. The
Figure 04 - Average revenue (US\$) from international tourist arrivals between 2006 and 2016

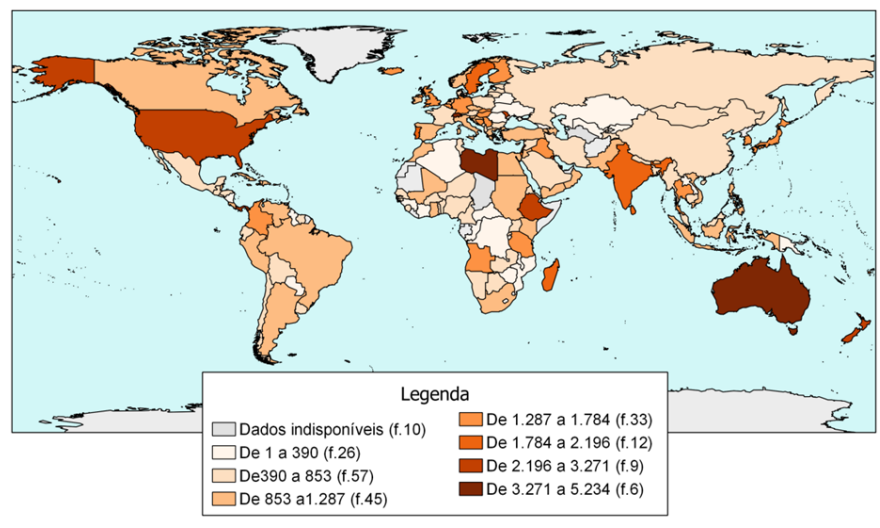

Source: elaborated by the authors

devaluation of South American currencies against the Euro should also be considered, making these results even more impressive. Another outstanding performance is that of Colombia and Panama, which fit a higher level in this same comparison.

\section{Variation in international travel revenues (2006- 2016)}

The variation in international tourism revenues between 2006 and 2016 is illustrated in Figure 5 map. The highest rates with, an over $8.22 \%$ increase are in Asia and Africa. Myanmar in Southeast Asia leads the ranking. In the African continent, the islands of Saint Thomas and Prince are the only countries in this class. Also, the Near East countries stand out, such as Iraq, Qatar,

Figure 05 - Variation of international tourism revenue between 2006 and 2016

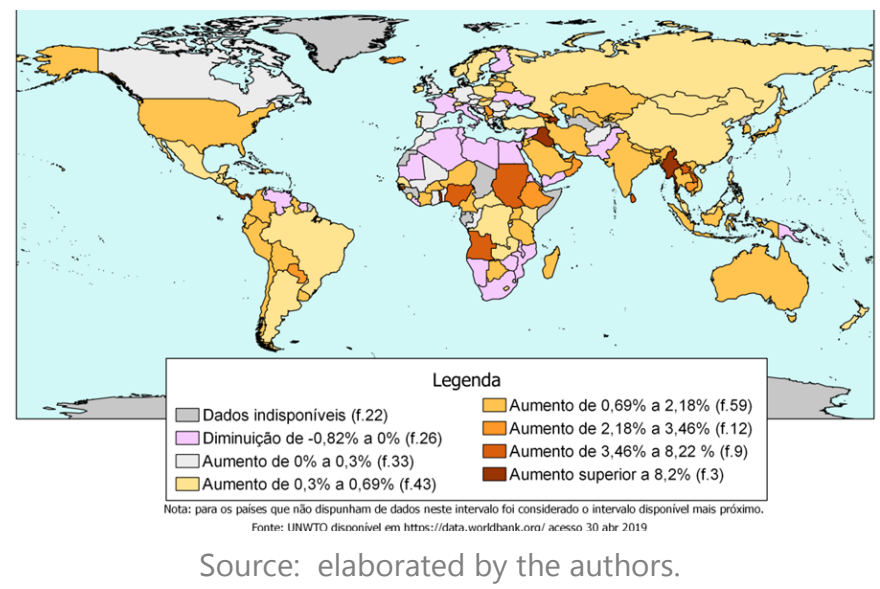


Azerbaijan, Tajikistan, and the West Bank. It can be argued that Myanmar's highest index came after the Saffron Revolution, which enabled the country's political and economic opening (FIDH, 2016). While the increase from 0.3 to 3.46 percent is noted on all continents, the decrease rates from -0.82 to 0 percent are concentrated in Africa and Europe. Nevertheless, they seem to respond to different dynamics. Europe, as a mature destination, no longer seems to have a large variation in the number of visitors. That, added to the 2008 crisis meant a decrease in its tourist revenue. Differently, the Northern African countries' revenue decline is linked with a decrease in tourist flows, implying a possible growth's resume in the future if greater political stability is achieved.

International tourist expenditures average (20062016)

In contrast to revenues, the map in Figure 6 illustrates the average in international tourism expenditure between the years 2006 and 2016. Here it is possible to consider the main tourist sending countries, that is, those that spend the most in visiting other nations. Generally, countries with the highest tourist spending average are in the Northern Hemisphere, except for Australia. Emerging countries like Brazil, India and Saudi Arabia also have a significant amount of spending.

Figure 06 - Average of international tourist expenditures between 2006 and 2016

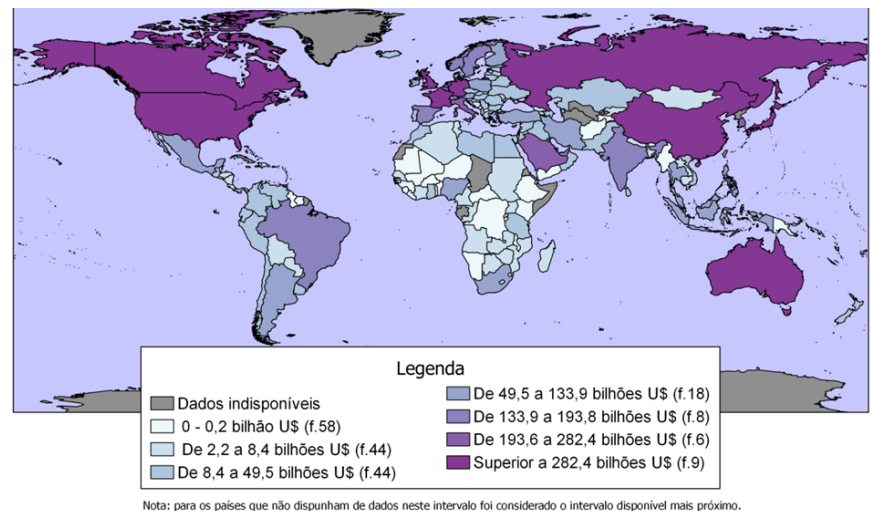

Source: elaborated by the authors
It can be noted that countries with the highest expenditure rates relate to the world's largest economies. In this case, Brazil and especially Australia have prominent roles in the southern hemisphere. Nevertheless, considering its relationship with GDP, Brazil spends less than the Oceania country. It's also worth mentioning Saudi Arabia, which does not even rank among the 15 largest economies and had an expense compared to the Netherlands .

\section{Variation in international travel expenditures (2006-} 2016)

The map in Figure 7 displays the international travel spending variation between 2006 and 2016. Few countries had a greater than $4.1 \%$ increase. The largest expression was East Timor, followed by Laos, Saint Thomas and Prince, Burma, Myanmar, Azerbaijan, Iraq, and The Gambia. China is the only country among the major economies that fits here, which is directly linked to the country's exponential economic growth. America and Oceania do not have any country with over $2.6 \%$ increase, except for Uruguay. Africa is the continent with the greatest heterogeneity between the statistics, as it is the case of the neighboring countries Zambia and the Democratic Republic of Congo.

Figure 07 - Variation of international tourist expenditure between 2006 and 2016

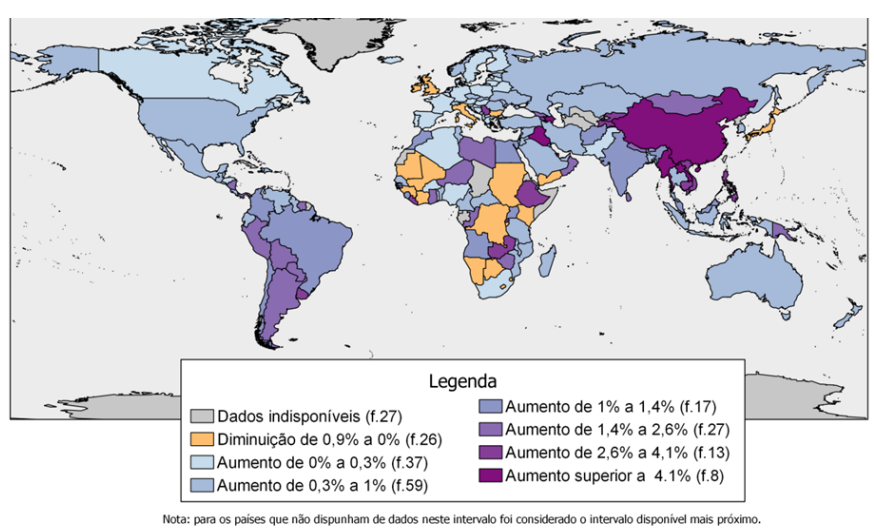

Source: elaborated by the authors

Africa is the continent with the lowest spending. 


\section{DISCUSSION}

Given the spatial distribution of these different international tourism indicators, it is possible to identify the following trends: in America, the tourism spotlight is the north of the continent. Mexico, the United States, and Canada have the largest flows of international tourists. This is due to geopolitical factors, since these countries are in the northern hemisphere, where there is a consolidated tourism offer and are served by major airlines, in the crossroads of important routes between Europe, Asia and the Americas itself. In addition to that are the stable economy and High Development Indexes of these states, which attracts not only tourists but also immigrants.

In South America, as attractive as the countries might be, the tourist flows are not very representative. Considering that countries such as Brazil and Argentina, the two major South American destinations, often go through economic and political instabilities. Another contributing factor is the distance from the main tourist -sending countries, mostly in the northern part of the globe. South America's main tourism market, as in other continents, is the interregional flow. Influenced by the reduced purchasing power of its countries when compared to developed countries. In this scenario, the Venezuelan crisis with a decrease in international tourist arrivals stands out in contrast to Paraguay's recent stability presently resulting in significant growth.

In Europe broadly speaking, the countries have a certain uniformity with a well-developed tourism offer. The transport infrastructure and the reduced territorial extension contributes to the ease of tourist mobility. In addition, there is the question that Europeans themselves move between countries, as the European Union enables the free movement of people, goods, and has a common currency. Ukraine stands out in this analysis with a sharp reduction in the number of international arrivals, possibly due to the Crimean War.

Asia is the continent with the largest variation in the number of tourist arrivals and revenue. Especially Southeast Asia, which had one of the highest growths in international arrivals. Myanmar opened the country for tourism after the Saffron Revolution, and although not having a high absolute number of tourists, just the fact of people visiting the site more often resulted in the world's largest increase in international arrivals over the analyzed period. Also noteworthy is this region's proximity to China, with its large increase in international tourism spending. In this regard, ASEAN China Air Traffic Agreement with its neighboring countries seemed to have positive implications for carriers supply and lower international tourism prices.

China, due to political and economic factors, is another major highlight in the recent international tourism panorama. After its political reform and market opening, China stands out in its economic growth, adopting a low-cost production policy with a versatile and agile industry that meets all the continent demands. In addition to that is the devalued currency and the high investments in tourism, China became one world's tourism hotspots, with predictions to become the future planet's most visited destination.

Africa, on the other hand, shows the greatest internal contrast between its nations. Analyzing the same period, some countries enjoyed an intense growth in international tourist arrivals while others regressed in the same proportion. The continent's northern countries, such as Libya and Egypt, where the Arab Spring began had a drastic decrease in arrivals, while sub-Saharan countries such as the Central African Republic and Côte d'Ivoire had an increase.

\section{CONCLUSION}

UNWTO data is a reference for an understanding of international tourism. This paper sought to discuss its recent dynamics using thematic cartography. By having the data stratified by nation and not regions, these maps allow a deeper understanding of each continent's tourism patterns and trends. It's noted how much tourism is permeable to international political and economic situation influences. It is also pointed out how some countries that stand out in absolute numbers, such as France and Spain, can be seen in a different perspective when considering the relative weight of tourism contribution, which is far for certain nations like Libya, Australia and island countries like the Caribbean and Pacific nations. 
Despite being an unavoidable reference for the public and scientific debate about tourism, UNWTO statistics are often mentioned in broad and generic terms in academic literature. The analyses made here and the presented maps contribute to the understanding of some trends regarding the countries tourist performances both at a regional and global level. Another contribution of this paper is to allow a more informed discussion and to foster debates in tourism education. This preliminary investigation could be expanded by with closer attention to the specifics of international tourism different regional circumstances. We sought to connect Tourism literature and concepts to International Relations studies, analyzing and investigating economic, political and geographical aspects of different countries.

\section{REFERÊNCIAS}

CAZES, G. (1992). Tourisme et Tiers-Monde: un bilan controversé. Paris: Harmattan,

FIDH. Saffron Revolution, (2007). Available at: <https:// www.fidh.org/IMG/pdf/BIRMÂNIA-DEC2007.pdf> on $01 / 10 / 2019$

LENOIR, N. \& LAPLACE, I. (2016). Liberalization in Southeast Asia: who is capturing the markets? WCTR 2016, World Conference on Transport Research, Shanghai, China.

NAÇÕES UNIDAS. Población, total. Available at: https:// datos.bancomundial.org/indicador/SP.POP.TOTL On 30 abr. 2019.

NETTO, A. \& TRIGO, L. (2016) (Org.). Turismo na América Latina: Casos de sucesso. Assis: Triunfal Gráfica e Editora, 366 p. Available at: <www.each.usp.br/turismo/livros/ turismo_na_america_latina_panosso_trigo.pdf $>$. On Oct 2019.

PIERI, V.S.G. (2014). Fluxos Turísticos Internacionais: uma proposta metodológica de análise sobre os (novos) destinos. Turismo em Análise, n. 25, v.3. Available at: http:// www.revistas.usp.br/rta/article/download/87678/pdf_14/ On Apr 2019.

PIMENTEL, M.R. (2017). Uma abordagem geográfica do Turismo: visitando Porto Alegre. Tese (Doutorado em Geografia) Instituto de Geociências, Universidade Federal do Rio Grande do Sul, Porto Alegre. Available at: https:// www.lume.ufrgs.br/handle/10183/170539 On Apr 2019.
SILVEIRA, M.A (2014). Geografia aplicada ao turismo: Fundamentos teóricos-práticos. Curitiba: Intersaberes. $327 \mathrm{p}$.

UNWTO (2019). Panorama OMT del Turismo Internacional. Edición 2018. Madri:. Available at: https://www.e-unwto.org/doi/ pdf/10.18111/9789284419890 On Apr 2019.

UNWTO (2010). Recomendaciones Internacionales para Estadísticas de Turismo 2008. Madri / Nova lorque. Available at: https://unstats.un.org/unsd/publication/Seriesm/ SeriesM_83rev1s.pdf on Apr 2019.

UNWTO. Turismo Internacional, gastos (US\$ a precios actuales). Available at: https://datos.bancomundial.org/indicador/ ST.I NT.XPND.CD?view=chart On 30 Apr 2019a.

UNWTO. Turismo Internacional, número de Arribos. Available at: https://datos.bancomundial.org/indicador/ST.INT.ARVL? view=chart On Apr 2019b.

UNWTO. Turismo Internacional, recibos (US\$ a precios actuales). Available at: https://datos.bancomundial.org/indicador/ ST.INT.RCPT.CD?view=chart On Apr 2019c. 